\title{
The Pieces KePt After Peace is KePt: Assessing the (Post-Exit) Legacies of Peace Operations ${ }^{1}$
}

John Gledhill (University of Oxford, Forum Editor)

\section{For publication in International Peacekeeping (2020).}

Do internationally-backed peace operations and state-building efforts leave legacies of sustainable peace and viable states? ${ }^{2}$ To answer this question -- which lies at the heart of the study and practice of multidimensional peacekeeping and peacebuilding -- we need to document conditions that prevail after peace operations have ended, and consider the extent to which those conditions are the consequences of international interventions. That is, to understand the lasting impact of peace operations, we need to examine what happens after missions close. While this may seem intuitive, scholars and practitioners have made surprisingly few efforts to systematically document and explain conditions on the ground in former host states after peace missions have exited. In this forum of nine short contributions, we aim to partly remedy that empirical gap and, in so doing, generate debate and discussion about the legacies of peace operations.

This introductory piece opens the forum by offering a brief overview of existing evaluations of peace(keeping) operations, highlighting the common tendency of analysts, scholars, and assessors to focus on the short-term, rather than lasting, impacts of interventions. I then identify and discuss three 'types' of legacy after peacekeepers exit and missions close, illustrating each by making reference to examples drawn from the contributions that follow.

\section{The 'Short-termism' of Existing Evaluations}

While there has been no shortage of efforts to evaluate the effects, and efficacy, of peace operations, those efforts have often -- though not always -- suffered from 'short-

\footnotetext{
${ }^{1}$ A number of the articles in this forum build on contributions to a workshop hosted at Brasenose College, Oxford, on 20 September, 2017. We thank contributors, participants, and sponsors of the workshop. We also thank colleagues and anonymous reviewers for comments on earlier drafts of our contributions, and the editors of International Peacekeeping.

${ }^{2}$ Recognizing that "boundaries between conflict prevention, peacemaking, peacekeeping, peacebuilding and peace enforcement have become increasingly blurred" (United Nations Peacekeeping, "Terminology"), this introductory essay uses the term 'peace operations' in reference to the various military and political interventions that the United Nations and regional actors realize in support of peace. More specific terms, such as (military) peacekeeping, are used when appropriate.
} 
termism'. That is, they have tended to focus on the short-to-medium term impacts of peace operations (typically, while peacekeepers are deployed), without systematically considering the lasting legacies of those operations, after mission closure. This has been the case for evaluations produced by policy actors and scholars alike.

On the policy side of the ledger, the United Nations (UN) has, unsurprisingly, made extensive efforts to evaluate the impact of its own peacekeeping and peacebuilding efforts. However, publicly available UN assessments tell us little about the longer-term legacies of UN interventions, after exit. Take, for example, the Secretary-General's regular status reports on the progress of ongoing peace missions; ${ }^{3}$ these documents can provide key insights into the impact of UN interventions while peacekeeping and follow-on missions remain active but, when missions end, the production and publication of status reports also slows or ends. Thus, the UN itself has recognized that, when "peacekeepers leave a country, it falls off the radar screen of the UN Security Council." "To be sure, the UN has given some consideration to the question of post-exit legacies in its periodic reviews of peace operations, such as the 'HIPPO' and 'Brahimi' reports, and Kofi Annan's report on the need for 'No Exit Without Strategy'.5 However, these reviews have primarily considered questions of mandate, organizational structure, and resourcing; as such, they have not aimed to document conditions on the ground in states that have formerly hosted peace operations. While there has been some documentation of countries monitored by the Peacebuilding Commission (PBC), such as Sierra Leone and Burundi, ${ }^{6}$ not all former host states are on the agenda of the PBC and so the Commission has offered only limited insights into the legacies of peace operations.

Academic evaluations of peace operations have also given limited attention to the lasting effects of interventions after missions close and peacekeepers exit. Consider quantitative assessments. ${ }^{7}$ One set of these has focused on the immediate or short-term consequences of peacekeeping by exploring the impact of troop deployments on the onset,

\footnotetext{
${ }^{3}$ Many of these reports are publicly available at https://www.un.org/securitycouncil/content/reports-secretarygeneral (last accessed 18 March, 2019).

${ }^{4}$ United Nations, "A More Secure World," 61. Note, however, that cases can remain formally on the UNSC's agenda.

${ }^{5}$ United Nations, "Uniting Our Strengths for Peace"; United Nations, "Brahimi Report"; United Nations Security Council, "No Exit Without Strategy".

${ }^{6}$ Bellamy, "The Institutionalisation of Peacebuilding," 204-06.

7 For an overview of such assessments, see Di Salvatore and Ruggeri, "Effectiveness of Peacekeeping Operations."
} 
duration, and/or intensity of ongoing conflicts. ${ }^{8}$ A second set of renowned studies has taken a somewhat longer-term perspective by investigating the (generally positive) impact of peacekeeping on the durability of peace following a cessation of hostilities. ${ }^{9}$ Even then, however, such works tend to offer limited insights into the legacies of peace operations after mission exit because they do not ordinarily isolate and examine subsets of cases in which peacekeepers have withdrawn, with a view to investigating the impact of peacekeeper withdrawal on security and/or the specific effects of peacekeeping that can be observed after mission closure. ${ }^{10}$ Quantitative studies also tend to explore the impact of peacekeeping on a relatively narrow set of outcomes: security and 'negative peace'. ${ }^{11}$ Where that is the case, they are not able to assess the wider range of legacies that multidimensional peace operations might leave in their wake. ${ }^{12}$

A number of qualitative and mixed-method evaluations, by contrast, have examined the broad range of outcomes that can follow from multidimensional interventions. Some qualitative scholars have adopted a comparative approach by first identifying a common set of evaluation criteria, ${ }^{13}$ and then using those criteria to assess the 'success' or 'failure' of selected peace operations. ${ }^{14}$ Other qualitative studies have focused on individual cases and explored the impact of UN peace missions on security and state capacity in countries such as Cambodia, Timor-Leste, Côte d'Ivoire, Liberia, Sierra Leone and beyond. ${ }^{15}$ Specific case studies, along with cross-national studies, are important for understanding the immediate effects of peace operations but, again, such studies tend to reveal little about lasting effects because they often focus on outcomes during periods of mission deployment, rather than trends after mission

\footnotetext{
${ }^{8}$ For example, Hultman et al., "United Nations Peacekeeping and Civilian Protection in Civil War"; Hultman et al., "Beyond Keeping Peace"; Ruggeri et al., "Winning the Peace Locally".

${ }^{9}$ For example, Beardsley, "The UN at the Peacemaking-Peacebuilding Nexus"; Caplan and Hoeffler, "Why Peace Endures"; Doyle and Sambanis, "International Peacebuilding"; Gilligan and Sergenti, "Do UN Interventions Cause Peace?".

${ }^{10}$ For discussions of incorporating mission exit into quantitative studies of peacekeeping efficacy, see Fortna, “Does Peacekeeping Keep Peace?” and Does Peacekeeping Work, Ch.5.

${ }^{11}$ Diehl and Druckman, "Multiple Peacekeeping Missions," 34.

${ }^{12}$ The work of Doyle and Sambanis is an exception to this rule, along with Brosig and Sempijja's recent study of "What Peacekeeping Leaves Behind."

${ }^{13}$ For overviews of evaluation criteria (including qualitative indicators), see Diehl and Druckman, "Evaluating Peace Operations"; Whalan, "Evaluating Integrated Peace Operations"; Peter, "Measuring the Success of Peace Operations".

${ }^{14}$ See, for example, contributions to Druckman and Diehl (eds.), Peace Operation Success.

${ }^{15}$ See Doyle and Suntharalingam, "The UN in Cambodia"; Smith and Dee, "East Timor"; Novosseloff, "The Many Lives of a Peacekeeping Mission"; Adebajo, UN Peacekeeping in Africa, Ch. 5. Also see selected evaluations of UN missions in Koops et al. (eds), The Oxford Handbook.
} 
closure. Multidimensional qualitative assessments also typically consider whether intended or mandated peacebuilding goals are realized, without giving extensive consideration to the various unintended consequences that can follow from the deployment of large-scale peace operations. While there are a number of studies of such unintended outcomes, ${ }^{16}$ those works ordinarily focus on the unintended effects of peacekeeping while troops remain on the ground (e.g. on the local economy), rather than unintended consequences that may (continue to) manifest themselves after peacekeepers leave.

In sum, existing evaluations of peace operations tend to prioritize short-term impacts rather than longer-term, post-exit legacies -- partly, perhaps, because collective attention and resources shift away from former host states after missions close, and partly because there are methodological challenges associated with tracing causal processes over long timeframes. ${ }^{17}$ Still, there are some partial exceptions. For example, early evaluations of peace operations offered by Doyle and Sambanis, and Howard, recognized the need to consider indicators of success/failure following the closure of peace(keeping) missions. ${ }^{18}$ Caplan (et al.), meanwhile, flagged the need to consider issues surrounding mission withdrawal. ${ }^{19}$ More recently, Beber et al. ${ }^{20}$ have offered a preliminary consideration of the impact of mission closure on 'peacekeeping economies', Dorussen has surveyed perceptions of post-exit security in TimorLeste, ${ }^{21}$ and Tansey has provided a methodological framework for assessing the legacies of state-building efforts. ${ }^{22}$ The contributions to this forum add to these works by considering the legacies of peace operations, with a particular emphasis on conditions after peacekeepers withdraw. To provide a platform for the studies that follow, the next section offers a brief discussion of the concept of 'legacy', as it pertains to the evaluation of peace operations.

\section{Conceptualizing (Post-Exit) Legacies in the Study of Peace Operations}

What is a 'legacy'? Intuitively, the concept is simple -- it is a "long-lasting effect of an event or process." 23 When unpacked, however, the concept becomes more complicated because

\footnotetext{
16 See, for example, Aning and Edu-Afful, "Unintended Impacts"; Hull et al., Managing Unintended Consequences; Jennings, "Life in a 'Peace-kept' City”.

${ }^{17}$ See discussion in Diehl and Druckman, "Evaluating Peace Operations."

${ }^{18}$ Doyle and Sambanis, Making War and Building Peace; Howard, UN Peacekeeping in Civil Wars.

${ }^{19}$ Caplan, "After Exit: Successor Missions"; Caplan (ed.), Exit Strategies and State Building.

${ }^{20}$ Beber et al., "Challenges and Pitfalls of Peacekeeping Economies."

${ }^{21}$ Dorussen, "Security Perception."

22 Tansey, "Evaluating the Legacies of State-Building."

${ }^{23}$ Oxford English Dictionary, "Legacy, n.."
} 
it implies a particular type of causal relationship in which an observed outcome is somewhat removed from its root cause. While a detailed discussion of causality is beyond the scope of this short essay, I want to propose three sets of causal paths and associated 'ideal type' legacies that are pertinent when considering the effects that peace operations may leave in their wake (see Table 1). Since the contributors to this forum (implicitly) explore one or more of these causal processes and associated legacy types in their essays, I illustrate each type by making reference to relevant contributions that follow. ${ }^{24}$

Table 1: Types of Peace Operation Legacy

\begin{tabular}{|c|c|}
\hline Legacy Types & Causal Paths \\
\hline Direct legacy & Institutionalized structures \\
\hline Indirect legacy & Path dependent processes \\
\hline Interrupted legacy & Critical disjunctures \\
(of pre-peace operation practices) & \\
\hline
\end{tabular}

In the first causal path, institutionalized structures and practices create direct legacies. In terms of peace operations, this type of legacy is observed when institutions, structures, or practices are put in place by peacebuilders during the period of mission deployment and those arrangements simply persist after the peace operation ends. ${ }^{25}$ Such direct legacies are discussed in the contribution from Karin Landgren, who draws attention to some of the positive unintended consequences of UN interventions. Specifically, she notes that UN missions build physical infrastructure (such as roads) and establish best bureaucratic practices within host states in order to facilitate the execution of UN mandates; those structures and practices can then remain in place -- largely unchanged -- after exit. Sabrina Karim also explores direct legacies by documenting security sector reforms that were put in place during the early stages of the UN Mission in Liberia (UNMIL), noting that a number of those reforms have largely held since UNMIL closed at the end of March 2018. The fact that both contributions focus on outcomes that were observed shortly after mission exit could suggest that direct legacies are most readily identifiable immediately after peace operations close. As time passes, however, the effects of UN interventions may become diluted as their causal influence interacts with, or

\footnotetext{
${ }^{24}$ Note that some contributions refer to diverse outcomes and, thus, diverse types of legacy. In this introduction, however, I draw selectively on the studies that follow in order to facilitate illustration of the typology that I introduce.

${ }^{25}$ Based on Wittenberg, "Conceptualizing Historical Legacies," 372.
} 
is overwritten by, diverse domestic and/or international political processes. ${ }^{26}$ Exactly how the process of dilution plays out, however, is likely to vary across cases and is an area that demands further research, going forward.

While direct legacies may be most readily observed during the immediate post-exit period, this is not necessarily the case for indirect legacies, which come about through path dependent causal processes. ${ }^{27}$ These processes begin during periods of intervention, when international actors and their local partners take major decisions and actions in key policy areas on a daily basis. Those decisions and actions shape conditions on the ground while peace missions are ongoing and peacekeepers remain in situ. Importantly, however, they can also have causal effects that outlast the period of deployment because actors in host states then adapt their expectations, behaviours, and interests in response to the initial interventions. Those adaptations, in turn, narrow the subsequent range of choices, actions, and possible outcomes in a given issue area. In that way, interventions from peacebuilders can initiate causal sequences that inform outcomes for years thereafter -- including many years after peace missions close. In his contribution, Kheang Un discusses such indirect legacies when considering whether Cambodia's current combination of electoral authoritarianism and economic development can be traced back to decisions that were taken during the period of UNTAC deployment (199293). Norrie MacQueen looks at whether Portugal's roles in UN peace operations in (its former colony) Timor-Leste after 1999 have contributed to a (partial) restoration of Portuguese influence over the now-independent country. And Diana Koester documents growth in human trafficking and forced prostitution alongside the deployment of NATO forces and UN police in Bosnia during the 1990s, before explaining how exploitative practices and institutions established at that time continue to create challenges for victims of trafficking and Bosnian state organs many years later. In each case, the authors point to the lasting effects of international interventions but their essays also reveal the methodological challenges associated with tracing causal processes over the medium-to-long term after exit. ${ }^{28}$

In a third post-exit scenario, causes are even further removed from effects. Indeed, observed outcomes are not directly tied to peace operation interventions at all; rather, outcomes can be seen as interrupted legacies of conditions that were in place prior to mission

\footnotetext{
${ }^{26}$ Diehl and Druckman, "Multiple Peacekeeping Missions," 45.

${ }^{27}$ On path dependence and legacies, see Collier and Collier, "Critical Junctures and Historical Legacies"; Pierson, "Increasing Returns, Path Dependence."

${ }^{28}$ See discussion in Diehl and Druckman, "Evaluating Peace Operations," 97.
} 
deployment. ${ }^{29}$ In this case, a set of antecedent conditions exist in a given conflict-affected country. A peace operation is then deployed and, due to interventions from peacekeepers and/or peacebuilders, conditions on the ground change throughout the period of mission deployment. However, when the peace operation ends and peacekeepers leave, there is a return to the status quo ante. In that way, the observed, post-exit outcomes are not actually legacies of peace operations. Instead, the period of mission deployment can be seen as a critical disjuncture, which temporarily breaks patterns of behaviour that are otherwise observed both before and after the peace operation. Such an arrangement is partly illustrated in Athena Kolbe's treatment of peacekeeping in Haiti. Specifically, she shows that the Haitian National Police force was weak and ineffective prior to the arrival of the MINUSTAH peacekeeping mission in 2004, and early signs have suggested that it will be similarly weak following the transition and to, and recent closure of, the MINUJUSTH follow-on mission -- despite the intervening years of UN-backed training and policing.

\section{Conclusion}

While the three causal paths that I have identified above, and the three associated legacy types, may provide a starting point for thinking about (variation in) the lasting effects of peace operations, they are just that -- a starting point. The scenarios described above are all simplifications of far more complex causal realities. So, while there is some heuristic benefit to recognizing 'ideal type' legacies, this should be balanced by recognition of the methodological challenges that are associated with assessing the effects of peace interventions -- particularly effects that endure after peacekeepers leave and peace missions close. Those challenges are diverse and include: issues associated with the availability and quality of relevant data; difficulty in isolating the impact of peace operations amidst causal 'noise' created by structures/actors that are not related to peace missions but which influence outcomes before and after mission deployment; ${ }^{30}$ the absence of a baseline understanding of the kinds of outcomes that we might expect to observe if multidimensional peace operations do indeed leave legacies; ${ }^{31}$ and more.

\footnotetext{
${ }^{29}$ This builds on logic articulated in Wittenberg, "Conceptualizing Historical Legacies," 373.

${ }^{30}$ See related discussions in Brosig and Sempijja, "What Peacekeeping Leaves Behind"; Tansey, "Evaluating the Legacies of State-Building."

${ }^{31}$ Diehl in Druckman et al., "Evaluating Peacekeeping Missions," 156.
} 
In the next contribution to this forum, Jessica Di Salvatore and Andrea Ruggeri continue the discussion by mapping trajectories of state capacity after the withdrawal of peace operations and, in so doing, highlight particular challenges that are associated with using quantitative methods to assess legacies. While those challenges are real, Di Salvatore and Ruggeri suggest that they can be partly mitigated through the use of multiple (quantitative, qualitative, survey-based) methods when studying legacies. The subsequent contributions go on to employ such diverse strategies, as authors consider the lasting impacts of peace operations across a range of cases. The first three case studies consider legacies over the medium-to-long term in Cambodia (Un), Timor-Leste (MacQueen), and Bosnia (Koester), ${ }^{32}$ and the next two studies consider possible legacies in two cases where UN peacekeeping missions have recently closed: Haiti (Kolbe) and Liberia (Karim). Karin Landgren then draws on her experience of leading UN peace operations in Liberia, Nepal, and Burundi to discuss the positive unintended legacies of those missions, before Richard Caplan concludes the forum by discussing methodological issues and highlighting scope for future research into the lasting effects of peace operations on state capacity, after missions close. Such research is needed, not just because it fills an empirical gap in academic literature but because it would allow policy makers to better evaluate the efficacy of international peacekeeping, peacebuilding, and statebuilding efforts. After all, we can ultimately only know if those efforts contribute to the construction of peaceful, sustainable states by looking at outcomes that manifest themselves after peacekeepers have withdrawn and the scaffolding of UN support has come down.

\section{Bibliography}

Adebajo, Adekeye. UN Peacekeeping in Africa: From the Suez Crisis to the Sudan Conflicts. Boulder \& Sunnyside: Lynne Rienner Publishers \& Fanele, 2011.

Aning, Kwesi, and Fiifi Edu-Afful. "Unintended Impacts and the Gendered Consequences of Peacekeeping Economies in Liberia." International Peacekeeping 20, no.1 (2013): 17-32.

Beardsley, Kyle. "The UN at the Peacemaking-Peacebuilding Nexus." Conflict Management and Peace Science 30, no. 4 (2013): 369-386.

Beber, Bernd, Michael Gilligan, Jenny Guardado, and Sabrina Karim. 2016. "Challenges and Pitfalls of Peacekeeping Economies." Working Paper, July 2016. https://www.nyu.edu/projects/beber/files/Beber_Gilligan_Guardado_Karim_PK_Economy.p df. Accessed 15 May, 2018.

\footnotetext{
${ }^{32}$ Recognizing that the international community's presence in Bosnia has substantially reduced but not 'exited'.
} 
Bellamy, Alex J. "The Institutionalisation of Peacebuilding: What Role for the UN Peacebuilding Commission?" In Oliver Richmond (ed.), Palgrave Advances in Peacebuilding: Critical Developments and Approaches, 193-212. London: Palgrave Macmillan, 2010.

Brosig, Malte, and Norman Sempijja. "What Peacekeeping Leaves Behind: Evaluating the Effects of Multi-Dimensional Peace Operations in Africa." Conflict, Security \& Development 17, no. 1 (2017): 21-52.

Caplan, Richard. "After Exit: Successor Missions and Peace Consolidation." Civil Wars 8 no. 3-4 (2006): 253-267.

Caplan, Richard (ed.). Exit Strategies and State Building. Oxford: Oxford University Press, 2012.

Caplan, Richard, and Anke Hoeffler. "Why Peace Endures: An Analysis of Post-conflict Stabilisation." European Journal of International Security 2, no. 2 (2017): 133-152.

Collier, Ruth B., and David Collier. "Critical Junctures and Historical Legacies", extracted from Ruth B. Collier and David Collier, Shaping the Political Arena: Critical Junctures, the Labor Movement, and Regime Dynamics in Latin America. Princeton: Princeton University Press, 1991. SSRN: https://papers.ssrn.com/abstract=1750509. Accessed 15 May, 2018.

Di Salvatore, Jessica, and Andrea Ruggeri. "Effectiveness of Peacekeeping Operations." In William Thompson (ed.), Oxford Research Encyclopedia of Politics (Online edition). New York: Oxford University Press, 2017.

Diehl, Paul F., and Daniel Druckman. "Multiple Peacekeeping Missions: Analysing Interdependence." International Peacekeeping 25, no.1 (2018): 28-51.

Diehl, Paul F., and Daniel Druckman. "Evaluating Peace Operations." In Joachim A. Koops et al. (eds.), The Oxford Handbook of United Nations Peacekeeping Operations (Online edition), 93-107. Oxford: Oxford University Press, 2015.

Dorussen, Han. "Security Perception after the Completion of UN Peacekeeping in TimorLeste." Peace Economics, Peace Science and Public Policy 21, no. 4 (2015): 453-458.

Doyle, Michael W., and Nicholas Sambanis. "International Peacebuilding: A Theoretical and Quantitative Analysis.” American Political Science Review 94, no. 4 (2000): 779-801.

Doyle, Michael W., and Nicholas Sambanis. Making War and Building Peace: United Nations Peace Operations. Princeton: Princeton University Press, 2006.

Doyle, Michael W., and Nishkala Suntharalingam. "The UN in Cambodia: Lessons for Complex Peacekeeping.” International Peacekeeping 1, no. 2 (1994): 117-147.

Druckman, Daniel, and Paul F. Diehl (eds.). Peace Operation Success: A Comparative Analysis. Leiden: Brill / Martinus Nijhoff Publishers, 2013.

Druckman, Daniel, et al. "Evaluating Peacekeeping Missions." Mershon International Studies Review 41, no. 1 (1997): 151-165. 
Fortna, Virginia Page. "Does Peacekeeping Keep Peace? International Intervention and the Duration of Peace after Civil War.” International Studies Quarterly 48, no. 2 (2004): 269-292.

Fortna, Virginia Page. Does Peacekeeping Work? Shaping Belligerents' Choices after Civil War. Princeton: Princeton University Press, 2008.

Gilligan, Michael J., and Ernest J. Sergenti. "Do UN Interventions Cause Peace? Using Matching to Improve Causal Inference." Quarterly Journal of Political Science 3, no. 2 (2008): 89-122.

Howard, Lise Morjé. UN Peacekeeping in Civil Wars. Cambridge: Cambridge University Press, 2007.

Hull, Cecilia et al. Managing Unintended Consequences of Peace Support Operations. Stockholm: Swedish Defence Research Agency, 2009.

Hultman, Lisa, Jacob Kathman, and Megan Shannon. "United Nations Peacekeeping and Civilian Protection in Civil War." American Journal of Political Science 57, no. 4 (2013): 875891.

Hultman, Lisa, Jacob Kathman, and Megan Shannon. 2014. "Beyond Keeping Peace: United Nations Effectiveness in the Midst of Fighting." American Political Science Review 108, no.4 (2014): 737-753.

Jennings, Kathleen M. "Life in a 'Peace-kept' City: Encounters with the Peacekeeping Economy." Journal of Intervention and Statebuilding 9, no.3 (2015): 296-315.

Koops, Joachim, Norrie MacQueen, Thierry Tardy, and Paul D. Williams (eds.). The Oxford Handbook of United Nations Peacekeeping Operations. Oxford: Oxford University Press, 2015.

Novosseloff, Alexandra. "The Many Lives of a Peacekeeping Mission: The UN Operation in Côte d'Ivoire." New York: International Peace Institute, 2018.

Oxford English Dictionary (Online). "Legacy, n.” Oxford: Oxford University Press, n.d. Available online: http://www.oed.com/view/Entry/107006. Accessed 23 March, 2018.

Peter, Mateja. "Measuring the Success of Peace Operations: Directions in Academic Literature." NUPI Working Paper 862. Oslo: NUPI, 2016.

Pierson, Paul. "Increasing Returns, Path Dependence, and the Study of Politics." American Political Science Review 94, no. 2 (2000): 251-267.

Ruggeri, Andrea, Han Dorussen, and Theodora-Ismene Gizelis. "Winning the Peace Locally: UN Peacekeeping and Local Conflict." International Organization 71, no. 1 (2017): 163-185.

Smith, Michael G. and Moreen Dee. "East Timor". In William J. Durch (ed.), Twenty-FirstCentury Peace Operations, 389-466. Washington: United States Institute of Peace, 2006.

Tansey, Oisín. "Evaluating the Legacies of State-Building: Success, Failure, and the Role of Responsibility.” International Studies Quarterly 58, no. 1 (2014): 174-186. 
United Nations. "Uniting Our Strengths for Peace - Politics, Partnership and People. Report of the High-Level Independent Panel on Peace Operations.” New York: United Nations, 2015.

United Nations. "A More Secure World: Our Shared Responsibility. Report of the High-level Panel on Threats, Challenges and Change.” A/59/565. 2004.

United Nations. [Brahimi Report] "Report of the Panel on United Nations Peace Operations." A/55/305-S/2000/809. 2000.

United Nations Peacekeeping. "Terminology" (n.d.):

https://peacekeeping.un.org/en/terminology (Accessed 13 December, 2019).

United Nations Security Council. "No Exit Without Strategy: Security Council DecisionMaking and the Closure or Transition of United Nations Peacekeeping Operations." S/2001/394. 2001.

Whalan, Jeni. "Evaluating Integrated Peace Operations." Stockholm: International Forum for the Challenges of Peace Operations, Occasional Papers, no.2, 2014.

Wittenberg, Jason. "Conceptualizing Historical Legacies." East European Politics and Societies: and Cultures 29, no. 2 (2015): 366-378. 